\title{
Physicochemical Properties and Anti-Microbial Activity of Local Black Soap and its Comparison with Ghana Soap with Respect to Nigerian Industrial Standard
}

\author{
A.O.Edah ${ }^{1}$, C.B.Nnoli ${ }^{2}$, D.F.Wetkum ${ }^{3}$ \\ ${ }^{1,2}$ Department of Chemistry, University of Jos, Jos Plateau State, Nigeria \\ ${ }^{3}$ Department of Microbiology, University of Jos, Jos plateau State, Nigeria \\ edahalex2005@gmail.com
}

\begin{abstract}
The production of soap using vegetable matter such as ashes from plantain peels was examined. The water extract of ashes derived from vegetable matter was reacted with Palm Kernel Oil with the aim of producing black soap of good quality. Studies have shown that plantain peels contain high potash. The physicochemical properties shows that the moisture content was $15.51 \%$ and $3.77 \%$, foam height was $620 \mathrm{ml}$ and $840 \mathrm{ml}$, free fatty acid was $2.18 \%$ and $1.83 \%$, total fatty matter was $66.27 \%$ and $72.23 \%$, matter insoluble in water was $4.93 \%$ and $7.70 \%$, matter insoluble in alcohol was $13.36 \%$ and $12.38 \%$ and $\mathrm{pH}$ was 9.62 and 8.45 for local black soap and Ghana soap respectively. The results compare favourably with the Nigerian Industrial Standard (NIS, 2015). Hence it showed good properties.The anti-microbial activity of the local black soap extract against the test organism (Staphylococcus aureus, Escherichia coli, salmonella typhi) which causes skin problems was effective using agar dilution method. The pattern of inhibition varies with the soap concentration and the test organism. The soap was more effective on S.aureus with maximum zone of growth inhibition of $42.5 \mathrm{~mm}$ at $500 \mathrm{mg} / \mathrm{ml}$. The minimum inhibitory concentration (MIC) was found to be $31.25 \mathrm{mg} / \mathrm{ml}$ for the entire test organism while the minimum bactericidal concentration (MBC) was $500 \mathrm{mg} / \mathrm{ml}$ for the entire test organism. The anti-microbial activities exhibited by local black soap in this study, justify the use of local black soap for treatment of skin problems.This research has shown that there is hope for waste management and wealth creation.
\end{abstract}

Keywords: plantain peels, palm kernel oil, soap, physicochemical properties, antimicrobial activity.

\section{INTRODUCTION}

Soap is a cleaning agent manufactured in granules, bars, flakes, or liquid form obtained from reacting salt of sodium or potassium of various fatty acids that are of natural origin (Warra, 2013). Also, soap is any water-soluble salt of fatty acids containing eight or more carbon atoms. Soaps are produced for varieties of purpose ranging from washing, bathing, medication etc. The cleansing action of the soap is due to the negative ions on the hydrocarbon chain attached to the carboxylic group of the fatty acids. The affinity of the hydrocarbon chain to oil and grease, while carboxylic group to water is the main reason soap is being used mostly with water for cleaning purposes. It is generally known that soap is produced by the saponification of a triglyceride (fat or oil). In the process, the triglyceride is reacted with a strong alkali (potassium or sodium hydroxide) to produce glycerol and fatty acid salts. The salt of the fatty acid is called soap. The equations below represent a typical saponification reaction.

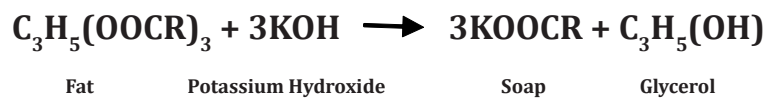

Where R represents the hydrocarbon chain or alkyl group. 
Physicochemical Properties and Anti-Microbial Activity of Local Black Soap and its Comparison with Ghana Soap with Respect to Nigerian Industrial Standard

Fatty Acids are straight-chain monocarboxylic acids. The commonest fatty acid used in soap making contains a range of $\mathrm{C}_{10}-\mathrm{C}_{20}$ and most often have an even number of carbon atoms including the carboxyl group carbon. Examples of such saturated fatty acid is palmitic acid $\left(\mathrm{CH}_{3}-\left(\mathrm{CH}_{2}\right)_{14}-\mathrm{CO}_{2} \mathrm{H}\right)$, while unsaturated fatty acids is oleic acid, $\mathrm{C}_{17} \mathrm{H}_{33} \mathrm{COOH}$. The constituent component of fatty acids, are chiefly oleic $\left(\mathrm{C}_{17} \mathrm{H}_{33} \mathrm{COOH}\right)$, stearic $\left(\mathrm{C}_{17} \mathrm{H}_{35} \mathrm{COOH}\right)$, palmitic $\left(\mathrm{C}_{15} \mathrm{H}_{31} \mathrm{COOH}\right)$, lauric $\left(\mathrm{C}_{11} \mathrm{H}_{23} \mathrm{COOH}\right)$ and myristic $\left(\mathrm{C}_{13} \mathrm{H}_{27} \mathrm{COOH}\right)$ acids; Hydrocarbon oils or paraffin are not suitable for soap-making, as far as chemical combination with the caustic alkali is concerned.

\section{BACKGROUND STUdY OF BLACK SOAP}

Black soap is made from the natural ingredients such as Plantain peels, Cocoa pods, Palm tree leaves and shea tree bark. African black soap also called "anago soap" "alata Samina" "Ose dudu" "Nchankota" or "Sabulu Solo" has long been used for healing Skin problems.

African black soap varies in colour depending on the materials used in making them. Different tribes and communities have adopted their own specific blend of oils and cooking techniques which can be seen in the different colour variation among black soap. Black soap is usually black or brownish in colour. It is $100 \%$ natural and contains no preservatives or chemicals. Its natural glycerin-rich content absorbs moisture from the air becomes soft if it is not stored properly in a cool, dry place or in a sealed polyethene bag. African black soap creates a soft, rich lather with enriched plant fats. This soap is mild, however some find black soap strong for their skin. A good soap must contain at least 15 percent of laurate for quick lathering.

The making of soap from ash-derived alkalis has been an old craft in Nigeria and many West African countries. Ash derived alkalis offer cheap alternatives to imported ones. Agricultural waste materials contain a good percentage of potash.These materials include palm bunch waste,cocoa pod,plantain peels,banana leaves, maize cob,wood,sugar beet waste and many others. When these materials are burnt in air, the resulting ashes contain oxides of potassium and sodium which when dissolved in water yield the corresponding hydroxides. (Onyebado et al., 2015). Potash is used for production of local soap and traditionally used as a cleaning agent. The alkali content of the ash-dried potash were said to be hydroxide of potassium and sodium (Onyekweie, 1996) or carbonates of potassium and sodium. (Tawio and Osinowo, 2001). Adewuyi et al., (2008), determined the potash yielding potentials of several African wood species and compared the ash as well as alkali contents. Ankrah, (1974) reported potash content of plantain peels for the purpose of soap making (Onyebado et al., 2002) there is a large consumption of plantain in Nigeria either as food or processed to produce plantain flour and local beer (Oladejo and Sanusi, 2008). In all these stated uses, there is little or no account of reuse or recycling of the waste peels expect for some insignificant use as animal feed. Previous studies carried out on the chemical contents of plantain fruit peels have been mainly on organic contents (Emaga et al., 2007), there is little or no report comparing both organic and inorganic chemical contents of the peel of plantain varieties.

Black soap can also contain humectants such as aloe-vera, Honey, Egg yolk egg white which helps to keep the body moist. Humectant is a hygroscopic substance which attracts and retains moisture. Humectant is a substance that is used to keep products moisture and affects the preservation of items, which can be used in cosmetic products, food and tobacco. Humectant-rich formulation contains simple alcoholic sugar that can increase skin hydration and helps remove and reduce thickness of the skin. All humectants have common hydroxyl groups which allow them to participate in hydrogen bonding and attracts moisture from the surface of the skin. Various humectants have different ways of behaving because they differ in water binding capacity at different humidity. It could act as a moisturizer. (Wikipedia, 2016).

Black soap with turmeric provide properties that are known for softening the skin and creating a smooth surface, it is also a source of vitamins A, E and iron and this helps to strengthen the skin and hair. Black soap 
Physicochemical Properties and Anti-Microbial Activity of Local Black Soap and its Comparison with Ghana Soap with Respect to Nigerian Industrial Standard

with turmeric has extra lightening affects. Black soap also has exfoliating properties and gives some protection from the sun.Plantain peel had been studied to have high potash content (Onyebado et al., 2002). The alkali contents of potash obtained from ashes of plantain peel was determined to evaluate the possibility of use as laboratory reagent. The result show that the ash content was 10\%; in terms of waste management, the volume of plantain peel waste had been reduced by $90 \%$. Potash yield was $74.37 \%$. The final amount of ash disposed as waste would be $25.63 \%$, which implies an effective waste management by refuse.

Quotation methods of analysis to ascertain the quality of soap have also been reported. Parameters like moisture content, total fatty matter, total fatty acid, free alkaline, chloride content, unsaponified value, and water insoluble matter etc have been analyzed in detail.

\section{Materials AND Methods}

\section{Sample Collection and Preparation.}

The Plantain peels were collected from restaurants around Tina Junction Jos North Local Government Area of Plateau State and dried for a period of 3 weeks in the month of December. The palm kernel oil was bought from Terminus market in Jos North.

\section{Soap Making Process.}

$120 \mathrm{~g}$ of the ash sample was weighed in a big beaker and $500 \mathrm{mls}$ of water added and stirred and allowed to settle for about 48 hours then it was filtered using a glass funnel and cotton wool to obtain the alkali extract. The extract was heated and a known amount of oil was added to the alkali extract in the ratio 4:1 and heated over a hot plate with stirring until complete saponification occurs. The obtained soap result is granular in nature.

\section{Preparation Of Culture Media}

$5.0 \mathrm{~g}$ of Mueller Hinton agar was dissolved in $250 \mathrm{ml}$ of water and sterilized by autoclaving at $121^{\circ} \mathrm{C}$ for $15 \mathrm{mins}$. Cork borer of diameter $4 \mathrm{~mm}$ was used to bored five holes on the plate that was inoculated with a single strain organism isolate and about $0.2 \mathrm{~m}$ of diluted extract concentration was introduce into the holes bore with respect to the labels on the plate from the highest to the lowest concentration the plate was allowed to stand for 1 hour to ensure pre diffusion before incubation at $37^{\circ} \mathrm{c}$ for 24 hours. (Ndukwe et al., 2005, Aliyu, et al., 2009)

\section{Preparation Of Black Soap Extract For Sensitivity Test}

The soap extract $(5 \mathrm{~g})$ was transferred into a small bottle and $10 \mathrm{ml}$ of pepton water was added to it, the bottle was closed and shaken vigorously to ensure mixing. Double serial dilution was done with this to obtain $500 \mathrm{mg}$, $250 \mathrm{mg}, 125 \mathrm{mg}, 62.5 \mathrm{mg}$ and $31.25 \mathrm{mg}$ of the soap concentration respectively, these various concentration was introduced in the plate containing prepared culture media using Mueller Hinton agar. Gentamicin 10mg/ml was used as a standard control. The plate was left for 1 hour at room temperature to allow for the diffusion and then incubated at $37^{\circ} \mathrm{C}$ for 24 hours. The zones around the holes show inhibitation and was measured in mm using a transparent plastic rule line.

\section{Minimum Inhibitory Concentration (MIC)}

The MIC of the extract was determined using small bottles 5 for each organism isolate for the $500 \mathrm{mg}, 250 \mathrm{mg}$, $125 \mathrm{mg}, 62.5 \mathrm{mg}$, and $31.25 \mathrm{mg}$ different concentration $0.1 \mathrm{ml}$ of Escherichia coli, staphylococcus aureus and Samonella typhi was inoculated into the bottles containing diluted extract of the various concentrations and incubated at $37^{\circ} \mathrm{C}$ for 24 hours. (The MIC was determined according to the National Committee for clinical standard 1999) 
Physicochemical Properties and Anti-Microbial Activity of Local Black Soap and its Comparison with Ghana Soap with Respect to Nigerian Industrial Standard

\section{Minimum Bactericidal Concentration (MBC)}

The culture media was prepared using Mueller Hinton agar 5.0g of the agar was dissolved in $250 \mathrm{ml}$ distilled water and autoclave to sterilized at $121^{\circ} \mathrm{c}$ for $15 \mathrm{mins}$. At the concentration in which the organism isolate shows positive test (there was no growth in the bottles) small quantity was picked into a small culture media aseptically using aflame ware loop and then incubated at $37^{\circ} \mathrm{c}$ for 24 hours in the incubator this was done to subculture the isolate. (The MBC was determined according to the National Committee for clinical standard 1999)

\section{Determination of Physicochemical Properties}

Physicochemical propertiesof local soap and Ghana soap were determined according to the Standard Organization of Nigeria test methods (SON test methods 2015).

\section{RESULTS AND Discussion}

From the results in table 1, the physicochemical properties of local black soap and that of Ghana soap shows that the colour of Ghana soap is brown while that of local soap was dark brown.This is as a result of the raw materials used in producing the soap as well as the cooking process. The moisture content of Ghana soap was $3.77 \%$ while that of the locally produced soap was $15.51 \%$ which shows that the produced soap absorbed more water and is higher than the recommended percentage $(10-15) \%$ (Encyclopedia of industrial chemical analysis, 2007). Implication of high moisture content in soap is that the excess water could possibly react with any unsaponified neutral fat to give free fatty acid and glycerol in a process called hydrolyses of soap on storage. (Tewari, 2004). Foam height gotten from Ghana soap was $840 \mathrm{ml}$ and the local black soap was $620 \mathrm{ml}$ and both were relatively stable and good. It is within the range of NIS of 180 miminum. The result shows that the \% FFA for Ghana soap is $1.83 \%$ and that of the produced soap is $2.18 \%$ and higher than the NIS of 0.2 max.

The values of the total fatty matter (TFM) obtained for Ghana soap was $72.23 \%$ while that of local soap was $66.27 \%$ and is suitable for bathing due to its high total fatty matter and within the range of $60 \%$ minimum for NIS.

Water insoluble matter is a property that describes how insoluble the soap will be. It shows that the matter insoluble in water of Ghana soap was $7.70 \%$ while that of local black soap was $4.93 \%$ and NIS is $2.5 \%$ maximum. The matter insoluble in alcohol for Ghana soap was $12.38 \%$ while of local soap was $13.36 \%$ and NIS is $5 \%$ maximum. The amount of matter insoluble indicated the level of purity of the soap. The higher the level of matter insoluble the lower the purity of the soap and this impurity can be attributed to the level of impurity of the alkali used or the dirt's and impurities contained in the oil used for producing the soap.

Table1. Physicochemical properties of Local Black Soap and Ghana Soap with respect to NIS (Nigerian Industrial Standard)

\begin{tabular}{|l|l|l|l|}
\hline \multicolumn{1}{|c|}{ Parameters } & Local soap & Ghana soap & NIS \\
\hline Colour & Dark-brown & Brown & - \\
\hline$\% \mathrm{H}_{2} \mathrm{O}$ content & 15.51 & 3.77 & $15.00 \mathrm{max}$ \\
\hline Foam height $(\mathrm{ml})$ & 620.00 & 840.00 & $180.00 \mathrm{~min}$ \\
\hline \% Free fatty acid & 2.18 & 1.83 & $0.20 \mathrm{max}$ \\
\hline \% Total fatty matter & 66.27 & 72.23 & $60.00 \mathrm{~min}$ \\
\hline \%IW & 4.93 & 7.70 & 2.50 max \\
\hline \%IW & 13.36 & 12.38 & 5.00 max \\
\hline $\mathrm{pH}$ & 9.62 & 8.45 & $6.00-10.00$ \\
\hline
\end{tabular}

Where; MIA=Matter insoluble in alcohol

MIW=Matter insoluble in water

American Research Journal of Chemistry

Page 33 
Physicochemical Properties and Anti-Microbial Activity of Local Black Soap and its Comparison with Ghana Soap with Respect to Nigerian Industrial Standard

From table 2, 3 and 4, the anti-microbial activities shows that, the black soap extract was effective against certain bacteria such as E.coli, salmonella and S.aureus from the investigation carried out on the anti-bacterial activity of the soap. The soap was found to have higher activity with increasing concentration both on Gram-Negative and Gram-positive bacteria. Table 3 shows that the minimum inhibitory concentration (MIC) was determined with the following concentration $500 \mathrm{mg} / \mathrm{ml}, 250 \mathrm{mg} / \mathrm{ml}, 125 \mathrm{mg} / \mathrm{ml}, 62.5 \mathrm{mg} / \mathrm{ml}$, and $31.25 \mathrm{mg} / \mathrm{ml}$, the soap inhibited E,coli, salmonella and S.aureus at the concentration of $31.25 \mathrm{mg} / \mathrm{ml}, 31.25 \mathrm{mg} /$ $\mathrm{ml}$ and $31.25 \mathrm{mg} / \mathrm{ml}$ respectively. Table 4 show the minimum bactericidal concentration are $500 \mathrm{mg} / \mathrm{ml}$ for E.coli and S.typhi and S. aureus.

Table2. Susceptibility of the soap extract (black soap) on the test organisms. Zones of inhibition ( $\mathrm{mm})$, Concentration $(\mathrm{mg} / \mathrm{ml})$

\begin{tabular}{|l|l|l|l|l|l|l|}
\hline Test organisms & 500 & 250 & 125 & 61.5 & 31.25 & + VE C \\
\hline E-coli & 25 & 23.5 & 19.5 & 19 & 19 & 30 \\
\hline Salmonella & 20.5 & 19 & 18.5 & 17 & 17 & 27.5 \\
\hline S.aureus & 42.5 & 35 & 35 & 24.5 & 19.5 & 30 \\
\hline
\end{tabular}

Key - = No zone of inhibition

$=$ Positive control $(+\mathrm{ve} \mathrm{C})=10 \mathrm{mg} / \mathrm{ml}$

$12 \mathrm{~mm}$ and below=resistance

$13 \mathrm{~mm}$ and $14 \mathrm{~mm}=$ moderately sensitive

$15 \mathrm{~mm}$ and above=sensitive

Table3. Minimum Inhibitory Concentration (MIC) of Soap Extract on the Test Organisms

\begin{tabular}{|l|l|l|l|l|l|l|}
\hline Test organisms & 500 & 250 & 125 & 62.5 & 31.25 & MIC \\
\hline E.coli & - & - & - & - & - & 31.25 \\
\hline Salmonella & - & - & - & - & - & 31.25 \\
\hline S.aereus & - & - & - & - & - & 31.25 \\
\hline
\end{tabular}

Key; - = no growth, + = growth

Table4. Minimum Bactericidal Concentration (MBC)

\begin{tabular}{|l|l|l|l|l|l|l|}
\hline Conc $(\mathrm{mg} / \mathrm{ml})$ & 500 & 250 & 125 & 62.5 & 31.25 & MBC \\
\hline E.coli & - & - & - & - & - & 500 \\
\hline Samonella & - & - & - & - & - & 500 \\
\hline S. aureus & - & - & - & - & - & 500 \\
\hline
\end{tabular}

Key; - = no growth, + = growth

\section{CONCLUSION}

The production of soap from palm kernel oil with alkali made from ashes of plantain peel was successfully achieved. The soap produced indicates that exploitation of vegetable matter to generate alkali for soap production is worthwhile apart from the fact that our environment would be free of these agricultural wastes that makes them untidy. Considering all the results on the comparison of locally made black soap and Ghana 
Physicochemical Properties and Anti-Microbial Activity of Local Black Soap and its Comparison with Ghana Soap with Respect to Nigerian Industrial Standard

soap, the production of local black soap should be encouraged since it has properties that are beneficial to a healthy skin. The data on black soap shows that it can compete favorably with other toilet soaps. The apparent deviation could be due to the crude nature of the soap and that of raw materials used for production. This research has shown that there is hope for waste management and wealth creation.

The antimicrobial activity exhibited by the black soap extract against the test organism that are associated with various skin infections have provided scientific justification for the use of black soap in treating skin infections.

\section{REFERENCES}

1. Adewuyi, G.O., OSbi-Egbedi, N.O., and Babayemi, J.0. (2008). Evaluation of ten different wood Species for potash production, International Journal of Physical Science 3(3), ISSN: 2006-1064, 63-68.

2. Afrane, G. (1992). Learning of caustic potash from coco huskash, Bioresouce Technology 41(2), 101-104; DOI: 10.1016/0960-8524(92)90177-Y

3. Alfred, S. (1983): Soap manufacture and Soap, Commerce Pharmaceutical Journal. 14, 1883 - 84, 534

4. Ankrah, E.A. (1974). Chemical studies of some plant waste from Ghana, Journalofthe Science of Food and Agriculture 25(10), 1229-1232; DIO: 10.1002/jsfa.2740251006

5. Alfred, S. (1983): Soap manufacture and Soap, Commerce Pharmaceutical Journal. 14, 1883 - 84, 534

6. Onyegbado, C.O., Iyagba, E.T., and Okafor, O.J. (2015). Solid Soap Production using Plantain peels ash as source of alkali, Journal of Applied Sciences and Environmental Management 6(1), ISSN: 1119-8362, 73-77.

7. Onyekwere, C. (1996) Cassava Peels Ash: An Alternative Source of Alkali in Soap Production B.Eng. Thesis Department of Chemical Engineering, University of Port Harcourt, Port Harcourt, Nigeria, 1-33.

8. Schuman, K. and Siekman, K. (2005) Soaps in Ullmann's encyclopedia of industrial chemicals.

9. Standard Organization of Nigeria (SON) Test Methods (2015).

10. Taiwo, O.E., and Osinowo, F. A.O. (2001).Evaluation of various agro-wastes for traditional soap production, Bioresource Technology 79(1), 95-97.

11. Technical analysis manual, Chemistry division, chemical engineering department, A.C, Anna University (2002). Handbook for chemical analysis Griffin 2006 edition.

12. Kuye, A.O and Okorie C. (1990) Factors Affecting The Lixiviation of Palm Bunch Ash As A Source of Alkali For Soap Production Ife Journal of Technology $\underline{3}$ (2): 33-37

13. M.O Aremu, M.O. Ibrahim, I.T. and Bamidele, T.O. (2015) Physiochemical Characteristics of the extracted from some Nigerian plant foods - A Review, Chemical and Process Engineering Research, 23:36-52.

14. Nigerian Industrial Standard (NIS), 2015.

15. Nwoko, V.O. (1980) Chemical Processing Development. Proceedings of the $10^{\text {th }}$ Annual Conference of the Nigerian Society of Chemical Engineers 40 - 53.

16. Nwoko, V.O. (1982). Effects of Mixing Oils on the Preparation and Properties of Soap. Private Communications.

17. Encyclopedia of Industrial Chemical Analysis. (2007). Interscience Publishers Division of John Wiley \& Sons. $18: 179,180$ 
Physicochemical Properties and Anti-Microbial Activity of Local Black Soap and its Comparison with Ghana Soap with Respect to Nigerian Industrial Standard

18. Aliyu,M.S, Hanwa, U.A. Tjjani, M.B. Aliyu, A.B. and Ya'u, B (2009). Phytochemical and antibacterial properties of leaf extract of stereospermum kunthianum (Bignoniaceae).Nigerian Journal of basic and applied sciences,17(2):235-239

19. Ndukwe, I.G. Amptitan, J.O. and Isah, Y. (2005).Phytochemical and Antimicrobial Screening of the Crude Extractfrom the root, stem, barkand leaves ofVitellaria paradoxa.AfricanJournalofbiotechnology6(16):19051909

20. National Committee for Clinical Laboratory Standard (NCCLS) (1999). Performance Standards for Antimicrobial disc and dilutions of susceptibility test for bacteria isolated from animals. Pennsylvania, $\mathrm{X}$, USA, document (M31-A).

Citation: A.O.Edah, C.B.Nnoli, D.F.Wetkum, "Physicochemical Properties and Anti-Microbial Activity of Local Black Soap and its Comparison with Ghana Soap with Respect to Nigerian Industrial Standard". American Research Journal of Chemistry, 1(1); pp:30-36.

Copyright (C) A.O.Edah, C.B.Nnoli, D.F.Wetkum, This is an open access article distributed under the Creative Commons Attribution License, which permits unrestricted use, distribution, and reproduction in any medium, provided the original work is properly cited. 